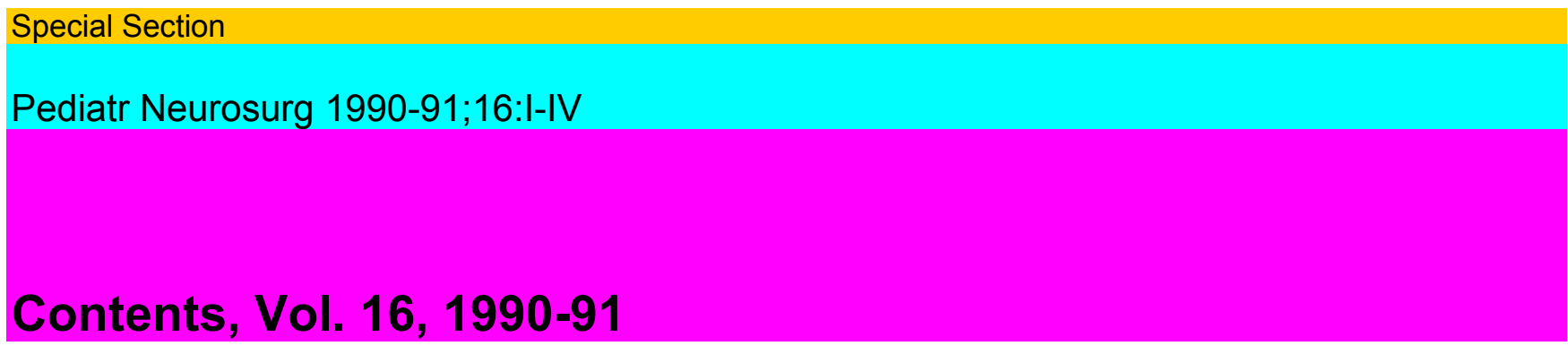

Vol. 16, 1990-91

Official Journal of the American Society of Pediatric Neurosurgery (ASPN)

Founded 1985 by E.B. Hendrick and D.H. Reigel

(formerly 'Pediatric Neuroscience')

\title{
Editor-in-Chief Editorial Board
}

F.J. Epstein, New York, N.Y. Pediatric Neurobiology Pediatric Neuropathology

Managing Editor R.J. Lemire, Seattle, Wash. L. Becker, Toronto

D.H. Reigel, Pittsburgh, Pa. N.J. Lenn, Stoney Brook, N.Y. M. Norman, Vancouver

Review Section Heads D.G. McLone, Chicago, 111. L.B. Rorke, Philadelphia, Pa.

R.P. Humphreys, Toronto Pediatric Neuro-Oncology Pediatric Neuroimaging

(Pediatric Neurosurgery) C.C. Bailey, Leeds B. Kendall, London

D.G. McLone, Chicago, 111. L.E. Kun, Memphis, Tenn. C. Raybaud, Marseille

(Pediatric Neurobiology) R.J. Packer, Washington, D.C. R.A. Zimmerman,

K. Takakura, Tokyo Philadelphia, Pa.

RJ. Packer, Washington, D.C. T. Tomita, Chicago, 111.

(Pediatric Neuro-Oncology) Pediatric Neurosurgery

L.B. Rorke, Philadelphia, Pa. C. Di Rocco, Rome

(Pediatric Neuropathology) R. Humphreys, Toronto

R.A. Zimmerman, $\quad$ D. Klein, Buffalo, N.Y.

Philadelphia, Pa. A. Menezes, Iowa City, Iowa

(Pediatric Neuroimaging) M. O’Brien, Atlanta, Ga.

H. Rekate, Phoenix, Ariz.

C. Sainte-Rose, Paris

R. Scott, Boston, Mass.

M. Walker, Salt Lake City, Utah

\section{KARGER}

S. Karger $\cdot$ Medical and Scientific Publishers

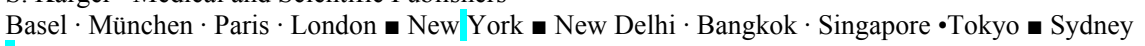

ug Dosage The authors and the publisher have exerted every effort to ensure that drug selection and dosage set forth in this text are in accord with current recommendations and practice at the time of publication. However, in view of ongoing research, changes in government regulations, and the constant flow of information relating to drug therapy and drug reactions, the reader is urged to check the package insert for each drug for any change in indications and dosage and for added warnings and precautions. This is particularly important when the recommended agent is a new and/or infrequently employed drug. All rights reserved.

No part of this publication may be translated into other languages, reproduced or utilized in any form or by any means, electronic or mechanical, including photocopying, recording, microcopying, or by any information storage and retrieval system, without permission in writing from the publisher or, in the case of photocopying, direct payment of a specified fee to the Copyright Clearance Center (see 'Information for Readers and Subscribers').

(C) Copyright 1990-91 by S. Karger AG, P.O. Box, CH- 4009 Basel (Switzerland) Printed in Switzerland on acid-free paper by Werner Druck AG, Basel

\section{Contents Vol. 16,1990-91}

No. 1 


$$
\text { No. } 2
$$

1

Editorial Note

Original Papers

Toward the Prediction of Neurological Injury from Tethered Spinal Cord: Investigation of Cord Motion with Magnetic Resonance

McCullough, D.C.; Levy, L.M.; DiChiro, G.; Johnson, D.L. 3

Tethered Cord as a Cause of Scoliosis in Children with a My-elomeningocele McLone, D.G.; Herman, J.M.; Gabrieli, A.P.; Dias, L. . 8 Moyamoya-Like Disease in Down's Syndrome

Goldstein, E.M.; Singer, H.S 14

Posttraumatic Meningitis in Adolescents and Children

Wilson, N.W.; Copeland, B.; Bastian, J.F

Pharyngeal Abscess with External Carotid Artery Erosion and Pseudoaneurysm. A Combined Radiologic and Surgical Management

Gonda, R.L., Jr.; Gutierrez, O.H.; Hengerer, A.S.; De

Weese, J.A 21

Cerebellar Mutism after Posterior Fossa Surgery

Dietze, D.D., Jr.; Mickle, J.P 25

Spinal Dysraphism in Achondroplasia

Phadke, R.V.; Phadke, S.R.; Chakravarti, A.L 32

Custom Fitted Thermoplastic Minerva Jackets in the Treat

ment of Cervical Spine Instability in Preschool Age Chil

dren

Gaskill, S.J.; Marlin, A.E 35

Familial Spastic Paraparesis: A Case of a Mitochondrial Dis

order

Beltran, R.S.; Coker, S.B 40

Case Reports

Diffuse Intravascular Coagulation Associated with Brain Tu

mor Surgery in Children

Huang, P.S.; Koo, K.E

43

Magnetic Resonance Imaging Diagnosis of a Cerebral Aneu-rysm in an Infant. Case Report and Review of the Literature

Putty, T.K.; Luerssen, T.G.; Campbell, R.L.; Boaz, J.C.;

Edwards, M.K $\quad 48$

Letters to the Editor

Response to the Comments on 'Intracranial Tuberculomas in

Children: An Assessment of a Therapeutic 4-Drug Trial in

35 Children' by G.S. Prakash et al.

Peter, J.C.; Domingo, Z 52

Intracranial Tuberculomas

Prakash, G.S.; Abraham, J.; Chandy, M.J.; Rajshekhar, V.;

Ghosh, S.; Joseph, T 54

Under the Knife

Gerland, K.; Epstein, F.J 56

Announcement 42 


\section{Original Papers}

Prognostic Factors in Childhood Ependymomas

Sutton, L.N.; Goldwein, J.; Perilongo, G.; Lang, B.; Schut, L.;

Rorke, L.; Packer, R.J

57

Management of Intracranial Neoplasms in Children with Neu-

rofibromatosis Type 1 and 2

Cohen, B.H.; Kaplan, A.M.; Packer, R.J

66

Brain Stem Gliomas: A Classification System Based on Magnetic Resonance Imaging

Barkovich, A.J.; Krischer, J.; Kun, L.A.; Packer, R.J.; Zim

merman, R.A.; Freeman, C.R.; Wara, W.M.; Albright, L.;

Allen, J.C.; Hoffman, H.J

73

Abstracts

Abstracts of the 4th International Symposium on Pediatric

Neuro-Oncology,

November 14-16, 1991, Tokyo

85

No. 3

Editorial

Pediatric Neurosurgery - Matchmaker of Law and Medicine

McLaurin, R.L

133

\section{Original Papers}

Cytological and Cytoarchitectural Changes in the Feline Cere bral Cortex during Experimental Infantile Hydrocephalus

Wright, L.C.; McAllister, J.P., II; Katz, S.D.; Miller, D.W.;

Lovely, T.J.; Salotto, A.G.; Wolfson, B.J

Intracranial Germ Cell Tumors in Children: An Immunohisto-

chemical and Electron Microscopic Study

Felix, I.; Becker, L.E

Management of the Dandy-Walker Syndrome

Bindal, A.K.; Storrs, B.B.; McLone, D.G

Central Nervous System Malformations and the VATER Asso

ciation

Raffel, C; Litofsky, S.; McComb, J.G 170

Cervical Neuroschisis and Meningocoele Manque in Type I

(No Neck) Klippel-Feil Syndrome

Cochrane, D.D.; Haslam, R.H.A.; Myles, S.T

Aneurysms of the Distal Anterior Cerebral Artery in Infants

Frank, E.; Zusman, E

179

Two Siblings with the Chiari I Malformation

Herman, M.D.; Cheek, W.R.; Storrs, B.B 


\section{Contents}

No. 4-5 


\section{No. 6}

\section{The E. Bruce Hendrick Festschrift}

\section{Dedication to E. Bruce Hendrick}

Humphreys, R.P 189

Ventricular Volume in Infantile Hydrocephalus and Its Relationship to Intracranial Pressure and Cerebrospinal Fluid

Clearance before and after Treatment: A Preliminary

Study

Maixner, W.J.; Morgan, M.K.; Besser, M.; Johnston, I.H. 191 Effect of Subcutaneous Implantation of Anti-Siphon Devices on CSF Shunt Function *

da Silva, M.C.; Drake, J.M 197

Effect of Population Characteristics on Head Injury Mortality

Shedden, P.M.; Moulton, R.J.; Sullivan, I.; Hotz, G.; Tucker,

W.S.; Muller, P.J 203

Evaluation, Surgical Approach and Outcome of Seizure Patients with Gangliogliomas

Otsubo, H.; Hoffman, H.J.; Humphreys, R.P.; Hendrick,

E.B.; Drake, J.M.; Hwang, P.A.; Becker, L.E.; Chuang, S.H. 208 A Critical Appraisal of the Role of Brachytherapy for Pediatric Brain Tumors

Bernstein, M.; Laperriere, N.J

Stereotactic Radiosurgery in Children and Adolescents

Kondziolka, D.; Lunsford, L.D.; Flickinger, J.C 219

Chiari I Malformation: A Review of 43 Patients

Nohria, V.; Oakes, W.J 222

Development of Symptomatic Chiari Malformation in a Child

with Craniofacial Dysmorphism

Frim, D.M.; Jones, D.; Goumnerova, L 228

Apnea in Patients with Myelomeningocele

Cochrane, D.D.; Adderley, R.; White, C.P.; Norman, M.;

Steinbok, $\mathrm{P} \quad 232$

Magnetic Resonance Imaging in the Pre-Operative Assessment

of Closed Spinal Dysraphism in Children

O’Neill, P.; Stack, J.P 240

Diastematomyelia in 172 Children: The Impact of Modern

Neuroradiology

Harwood-Nash, D.C.; McHugh, K 247

Diastematomyelia in Adults. A Review

Russell, N.A.; Benoit, B.G.; Joaquin, A.J

Congenital Dermal Sinus Presenting in a 62-Year-Old-Man

Feely, M.P.; Levy, W.J.; Schreiner, M 258

Mondini Dysplasia: Spontaneous Cerebrospinal Fluid Otor-

rhea. New Perspectives in Management

Wilson, J.T.; Leivy, S.W.; Sofferman, R.A.; Wald, S.L. . 260 Reduction Cranioplasty for Craniocerebral Disproportion in Infancy: Indications and Technique

Piatt, J.H., Jr.; Arguelles, J.H 265

Skull Repair in Children

Hockley, A.D.; Goldin, J.H.; Wake, M.J.C.; Iqbal, J. ... 271 Choroid Plexus Tumors in Infants

Knierim, D.S 276 


\section{Original Papers}

Brain Stem Cavernous Angiomas in Children

Scott, R.M 281

A Prospective, Randomized Study of Shunt Function and

Infections as a Function of Shund Placement

Bierbrauer, K.S.; Storrs, B.B.; McLone, D.G.; Tomita, T.;

Dauser, R287

Ototoxic Effect of Cisplatin in Children with Brain Tumors

Cohen, B.H.; Zweidler, P.; Goldwein, J.W.; Molloy, J.;

Packer, R.J 292

Repair of Compound-Depressed Skull Fractures in Children

with Replacement of Bone Fragments

Blankenship, J.B.; Chadduck, W.M.; Boop, F.A 297

Pathophysiology of Isolated Lateral Ventriculomegaly in

Shunted Myelodysplastic Children

Berger, M.S.; Sundsten, J.; Lemire, R.J.; Silbergeld, D.;

Newell, D.; Shurtleff, D 301

Spectrum of the Syndrome of the Isolated Fourth Ventricle in

Posthemorrhagic Hydrocephalus of the Premature Infant

James, H.E 305

Disconnection as a Cause of Ventriculoperitoneal Shunt Malfunction in Multicomponent Shunt Systems

Aldrich, E.F.; Harmann, P 309

Technical Note

Posterior Flank Approach to the Peritoneum for Ventriculoperitoneal Shunting

Willison, CD.; Kopitnik, T.A., Jr.; Kaufman, H.H.; Tarry,

W.; Vaughan, R 313

\section{Case Reports}

Adenovirus Encephalitis and Widespread Ependymitis in a Child with AIDS Anders, K.H.; Park, C.-S.; Cornford, M.E.; Vinters, H.V.

316

Salmonella Osteomyelitis with Epidural Abscess. A Case Re

port with Review of Osteomyelitis in Children with Sickle

Cell Anemia

Martino, A.M.; Winfield, J.A 321

Ruptured Intracranial Aneurysm Presenting as Cerebral Infarction in a Young Child

Rojiani, A.M.; Poskitt, K.J.; Cochrane, D.D.; Macnab,

A.J.; Norman, M.G 326

Author Index 331

Subject Index 332 